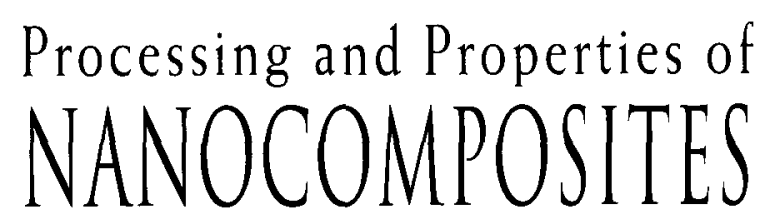


This page is intentionally left blank 


\section{Processing and Properties of NANOCOMPOSITES}

\section{Suresh G. Advani}

University of Delaware, USA 


\section{Published by}

World Scientific Publishing Co. Pte. Ltd.

5 Toh Tuck Link, Singapore 596224

USA office: 27 Warren Street, Suite 401-402, Hackensack, NJ 07601

UK office: 57 Shelton Street, Covent Garden, London WC2H 9HE

\section{British Library Cataloguing-in-Publication Data}

A catalogue record for this book is available from the British Library.

\section{PROCESSING AND PROPERTIES OF NANOCOMPOSITES}

Copyright $@ 2007$ by World Scientific Publishing Co. Pte. Ltd.

All rights reserved. This book, or parts thereof, may not be reproduced in any form or by any means, electronic or mechanical, including photocopying, recording or any information storage and retrieval system now known or to be invented, without written permission from the Publisher.

For photocopying of material in this volume, please pay a copying fee through the Copyright Clearance Center, Inc., 222 Rosewood Drive, Danvers, MA 01923, USA. In this case permission to photocopy is not required from the publisher.

ISBN 981-270-390-X 
This book is dedicated to the memory of my parents, Kamla and Gopaldas Advani 
This page is intentionally left blank 


\section{Preface}

The field on nanotechnology is still in its infancy but continues to progress at a much faster rate that any other field. Many methods to synthesize nano particles, disperse them in a carrying fluid to form a composite and exploit its extraordinary properties is the goal and dream of many researchers engaged in this field. It is not possible to cover every nano particulate matter and its role in materials revolution. The approach adopted here was to focus on carbon nanotubes and nano clays and explore their importance and their role in composites. Hence the chapters presented in this book address processing, rheology, mechanical properties and their interaction with fiber composites. Thus, this book is a collection of nine chapters written by researchers who are at the forefront of their field which address the role of nano particles in composites. The first three chapters focus on the use of Carbon nanotubes in a composite. Chapter 1 is a succinct summary of the state of the art of the carbon nanotubes in composites. Chapter 2 focuses more on the aspects of processing with these nano particles in a suspension. Most research is focused in using these nanotubes sparingly in the composite and exhibit disproportionally better properties. Chapter 3 focuses on how to address higher loadings of these nanotubes and develop nanostructure materials. Chapter 4 explores the interaction between traditional fiber composites and use of nano particles in them in terms of benefits and property enhancement in addition to processing of such materials. Chapter 5 discusses in detail the rheology of suspensions that contain nanofibers and how one can modify existing models to describe their flow behavior. Chapters 6 through 9 address nano clay composites. Chapter 6 is a good overview of the state of the art of the nanoclay usage in various resins and composites. Chapter 7 focuses on the mechanical and physical property characterization of polymer clay nanocomposites. 
Chapter 8 discusses further use of nanoclays in thermoplastics and their use in glass fiber composites. Chapter 9 describes methods to prepare nanoclay suspensions with thermosets and the corresponding enhancement in properties. I would like to thank all the authors and reviewers in making this project into reality.

\author{
Suresh Advani \\ GW Laird Professor of Mechanical Engineering \\ Associate Director, Center for Composite Materials \\ University of Delaware
}




\section{Contents}

Preface

\section{Chapter 1}

Carbon Nanotube/Nanofibre Polymer Composites

Milo Shaffer and Jan Sandler

\section{Chapter 2}

Dispersion, Bonding and Orientation of Carbon Nanotubes in Polymer Matrices

Suresh Advani and Zhihang Fan

\section{Chapter 3}

SWNT Buckypaper Nanocomposites: High Nanotube Loading and Tailoring Nanostructures

Zhiyong (Richard) Liang, Ben Wang and Chuck Zhang

\section{Chapter 4}

Processing and Mechanical Properties Characterization of Hybrid Thermoset Polymer Composites with Micro-Fiber and Carbon Nano-Fiber Reinforcements

Kuang-Ting Hsiao

\section{Chapter 5}

Shear Rheology of Nanofiber Suspensions and Nanofiber/Polymer Melt Composites

Jianhua $\mathrm{Xu}$, Yingru Wang, Christopher Kagarise,

Kurt W. Koelling and Stephen E. Bechtel 
Chapter 6

Recent Advances in Polymer/Layered Silicate Nanocomposites:

An Overview from Science to Technology

Masami Okamoto

\section{Chapter 7}

Polymer-Clay Nanocomposites - A Review of Mechanical and Physical Properties

Zhong-Zhen Yu, Aravind Dasari, Yiu-Wing Mai

\section{Chapter 8}

Preparative Methods and Properties of Polypropylene/Layered Silicate Nanocomposites

Joong-Hee Lee, Prashantha Kalappa, Chang-Eui Hong,

Nam Hoon Kim and Gye-Hyoung

\section{Chapter 9}

Clay Nanocomposites Of Polyurethanes And Epoxies:

Preparation Methods And Properties

Sadhan C. Jana 